\title{
Improving students' writing skill by using cooperative learning (think, pair, share) technique at grade VIII-7 SMP Negeri 1 Padangsidimpuan
}

\author{
Disra $^{1}$, M. Zaim ${ }^{2}$, Yenni Rozimela ${ }^{3}$ \\ ${ }^{123}$ Universitas Negeri Padang, Padang - Indonesia, (disranspd123@gmail.com)
}

\begin{abstract}
This research was conducted to improve the students'writing skill at grade VIII-7 SMP Negeri 1 Padangsidimpuan.. It was due to the lack of the students' interest and less of communication or sharing ideas in writing activity, so they were not able to complete their writing tasks by organizing their ideas, use correct grammar, and choose vocabulary during learning and teaching process. This research was intended to improve the students' writing skill by using cooperative learning (think, pair, share) technique at grade VIII-7 SMP Negeri 1 Padangsidimpuan. It was hoped that by using this technique the students' writing skill of grade VIII-7 SMP Negeri 1 Padangsidimpuan could be improved. The participants of this research were the students of grade VIII-7 SMP Negeri 1 Padangsidimpuan in 2012 - 2013 acdemic year. After finishing the first and second cycle of the research, there was some improvement in writing test scores.
\end{abstract}

Keywords: Cooprative Learning, Students' writing skill, Imoroving

\section{Introduction}

Writing in English is very essential to develop the students' skills in secondary schools. In secondary school, the students are expected to fully develop their formal writing skills. In formal writing, the secondary students have to develop and know the essential matters dealing with writing. It includes the students' focusing on the issues and organization in writing a text. This is one of the reasons why the teachers in secondary schools should emphasis on it. Based on the KTSP curriculum 2006 of the Junior High School in teaching and learning process for the English class, the students should have been introduced to some kinds of texts, they are: narrative, recount, report, procedure, and descriptive texts. The students must be able to master the kinds of the texts. They must be able to organize the ideas, choose the words or vocabulary, and arrange the words in grammatical order to develop the topics into good sentences in English text. In achieving these purposes, it is necessary for students to know the steps or the procedures how to write a text.

So, teaching writing is the most difficult skill in the four English skills because there some steps or stages that the students should master before writing a text.

At first according to Brown (1994:53) focuses that there are two aspects of assessment, they are accuracy and fluency. Accuracy consists of vocabulary, grammar, style, and the fluency consists of 
meaning and spontaneity. So, The students can write English fluently if they produce good fluency and accuracy.

The second, O'Malley (1996: 132) suggests that there are some aspects to evaluate or to rate in writing skill. The aspects are content, vocabulary, grammar, coherence, and mechanics. And it is also supported.

O'Malley (1996: 132) suggests that there are some aspects to evaluate or to rate in writing skill. The aspects are content, vocabulary, grammar, coherence, and mechanics. And it is also supported by Hughes (1999: 16) develops the rubrics for the evaluation of writing as follows: Grammar; noticeable error of grammar or word order, Vocabulary; the use of vocabulary and idioms, Mechanic; the noticeable in punctuation or spelling, and form; clear progression of the organization of the ideas in the text well.

And then, Depdiknas (2005: 36) acknowledges that to evaluate students' writing, the teacher has to use the criteria which has been set previously and communicated with the students, such as; the use of vocabulary, grammar, cohesion, rhetorical or generic structure of the text, clear of ideas and spelling.

But based on the researcher's preliminary observation at grade VIII-7 of SMP Negeri 1 Padangsidimpuan where the researcher teaches English, he still finds that so many students who cannot write and understand a text. When the researcher asked them to write a text, only about $10 \%$ of the 20 students who got grade $80-100$ points, $30 \%$ of the 20 students who got grade $60-79$ points and the rest $60 \%$ of them got grade below 60 points. So, only about $10 \%$ of the 20 students who can write the text, $30 \%$ of the 20 students who do not really manage about their writing well and the rest $60 \%$ of the 20 students cannot write a text at all. The researcher wanted that more than about $60 \%$ of the students can write a text.

Moreover, once at the end of the class the researcher did an informal interview about the students' interest in studying English. In fact, about $90 \%$ of the 20 students in the classroom like English very much and the rest of them do not and abstain. However, about $80 \%$ of them responded that they do not like writing. Their responded that writing was a complicated skill which needed the mastery of other language aspects such as grammar, vocabulary, and writing mechanism.

Based on the problems above, the writer revealed one of the reasons why the problems of writing happened to the language learners. It was the technique used in teaching English writing. It means that this problem appeared because their learning was not contributed by any kind of techniques that can support or stimulate to express the students' desire, ideas or opinion in writing form.

It is necessary for both teachers and students to improve language learning technique, and to expect the students able to express their ideas in English writing. So, it is necessary to provide a suitable technique of writing to promote the students' learning process in English learning, especially in writing. Cooperative learning (Think, Pair, Share) technique is a learning technique by pairing or grouping the students in different levels of skill in small groups for the purpose of achieving an academic goal. It refers to an instruction method in which students at various performance and competence levels work together in small groups toward a common goal. The students are responsible for one another's learning as well as their own. Think-share-pair is the essence of the cooperative learning technique. Cooperative learning technique claims that the active exchange of ideas within small groups not only increases interest among the participants but also promotes critical thinking in solving problems. Thus, the success of the learning is when one student helps other students to be successful.

The purpose of the Introduction is to stimulate the reader's interest and to provide pertinent background information necessary to understand the rest of the paper. You must summarize the problem to be addressed, give background on the subject, discuss previous research on the topic, and 
explain exactly what the paper will address, why, and how. A good thing to avoid is making your introduction into a minireview. There is a huge amount of literature out there, but as a scientist you should be able to pick out the things that are most relevant to your work and explain why. This shows an editor/reviewer/reader that you really understand your area of research and that you can get straight to the most important issues.

Johnson (1975: 78) who identifies that "cooperative learning technique promotes mutual working among different level skills of students. It also promotes better communication, high acceptance and supports an increase in a variety of thinking strategies among individuals in the groups.

Vygotsky (1978:361) states that "cooperative learning technique is a technique of learning method in which a different intellectual levels of students are asked to work together to solve the learning problems. It will promote the intellectual of the students by working in different level skills than when they are asked to work individually.

In addition, Bruner (1985: 241) states that cooperative learning technique is a technique of learning where the students are put in small groups in different ability to solve the learning problems. Cooperative learning can improve the critical thinking of the students because they can share their knowledge and ideas. The peers' support system makes it possible for the learners to internalize both external knowledge and critical thinking skills.

The succesful of the teaching writing also deponds on the teacher's technique in implementing of the five elements of the cooperative learning (Think, Pair, Share) technique; Positive Interdependence where each group's member has a task, role and responsibility in the learning process. Face-to-Face Promotive Interaction where the members of the group of students promote each other success, students and explain to one another what they have or what they are learning and assist one another with understanding and completion of assignments. Individual accountability where each student must demonstrate the mastery of the content being studied and each student is accountable for their learning and work. Social Skills are the skills in effective communication, interpersonal and group, leadership, decision-making, trust-building, communication, and conflict-management skills. Group Processing is every group of the students must assess their effectiveness and decide how it can be improved. So, all of the elements of the cooperative learning technique are to promote the students' activity in sharing ideas in the learning process, so all the students can involve in the learning process to gain the goals of the learning.

Johnson and Smith (1991: 352) state that the elements of cooperative learning technique are: positive interdependence, individual accountability, face to face promotive interaction, social skills, and group processing. Positive interdependence is the obligation to achieve the goal. Individual accountability indicates to share of the work. Face to face is the interaction of the groups' work may be parceled out or individually. Social skills are encouraged and helped to practice the trust-building leadership, decision-making, and communication. The group processing is the teams' members set group goals.

\section{Method}

Johnson and Smith (1991: 352) state that the elements of cooperative learning technique are: positive interdependence, individual accountability, face to face promotive interaction, social skills, and group processing. Positive interdependence is the obligation to achieve the goal. Individual accountability indicates to share of the work. Face to face is the interaction of the groups' work may be parceled out or individually. Social skills are encouraged and helped to practice the trust-building leadership, decision-making, and communication. The group processing is the teams' members set group goals.

The participants of this research were the students at the grade VIII -7 of SMP Negeri 1 Padangsidimpuan. In applying this research, the teacher and collaborator were primarily involved. 
The participants of this research were the students at the grade VIII-7 of SMP Negeri 1 Padangsidimpuan which consisted of 20 students, 12 of them are females and the rest of the 8 students are males. It was conducted from April 2012 to June 2012. In applying this research, the researcher asked for one of other English teachers who taught at the same grade of the school to be a collaborator.

In this action research, the researcher and the collaborator were the key instruments of doing the research, where the researcher, as the observer was involved in the field of the activity in collecting the data observation, while the collaborator was involved in every cycle to observe the teacher's and the students' activities in applying this action research, here the researcher used supporting instruments, they are: test of writing skill, observation, and interview in order to answer the research questions.

In getting calculation of the data, the researcher used two kinds of data; quantitative and qualitative data. In getting calculation of the quantitative data, the researcher used a test, a test of writing by using the following formula:

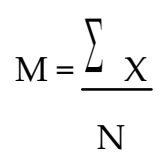

The description of class average/mean score:

$\sum$ = The sum of the score

$\mathrm{X}=$ Score

$\mathrm{N}=$ Number of students/number of indicator

$\mathrm{M}=$ Average/ Means Score

The average score of each student's writing skill was used to get the score conversion of the student's average score by using the scoring system and compared them to the average score of each indicator. And in getting the calculation of qualitative data, the researcher used an interview of the students' activities noted by the researcher.

\section{Results and Discussion}

After the implementation of cooperative learning (Think, Pair, Share) technique at grade VIII-7 of SMP Negeri 1 Padangsidimpuan, the students' writing kill improved. The improvement of the students' writing skill can be seen in the following diagram:

The diagram of the students's writing scores in pre-test, and the tests in cycle 1 and 2

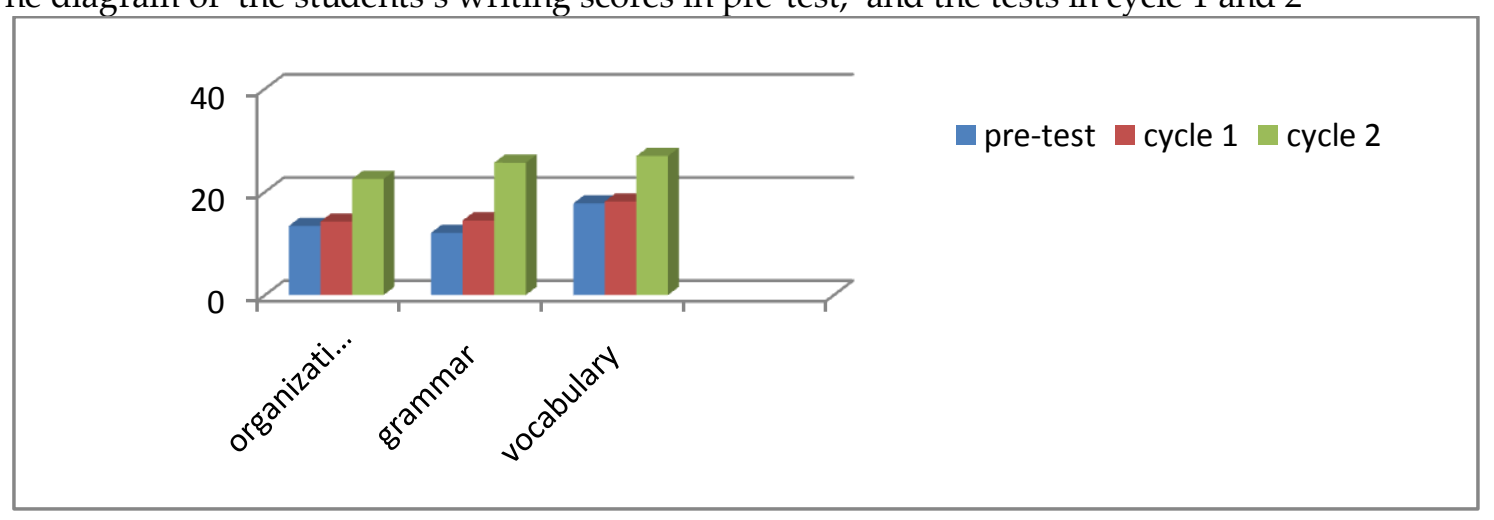

From the diagram above it can be seen that after implementation of the cooperative learning (Think, Pair, Share) technique the students' writing skill in the three aspects of writing; organization, 
grammar, and vocabulary were improved. It was proved from the two cycles of the implementation of the cooperative learning (Think, Pair, Share) technique, the students' writing skill better improved.

Besides that, the were some factors that infuence the changes of the students'writing skill by using cooperative learning (Think, Pair, Share) technique, as seen below:

Factors that influence the students' writing skill

1. Teaching technique

2. Learning Material

Based on the findings of the research, it can be concluded that the application of cooperative learning (Think, Pair, Share) technique better improved the students' writing skill in class. This was supported by Nurjannah (2007), Attamin (2007), Efendi (2008), Zuhri (2009), and Abdillah (2010) who have proven the effectiviness of applying cooperative learning (Think, Pair, Share) technique to solve the teaching and learning problems in writing skill, especially in the writing aspects of the organization, vocabulary and grammar among the partners and in groups.

In addition, it was also supported by the theory of Nunan (1999:35) who states that Writing skill is well formed of sentences which are integrated highly structured paragraphs. The accuracy of grammar is one of the language components that is very dominant in determining the quality of the language produced. Most people use language in both spoken and written forms that can develop an appreciation for the interrelation of purposes.In this case, it is clear that the sharing ideas and leading the students' activities are important factors in application of the cooperative learning.

\section{Conclusions}

To improve the students' writing skill there are some factors; the teacher's technique and the teaching material are the main factors. But the teacher's technique is the most dominant factor, so the teacher should used a good technique in teaching, especially in teaching writing. The implementation of cooperative learning in teaching writing in English text at grade VIII-7 SMP Negeri 1 padangsidimpuan better improved.

\section{References}

Abdillah, (2010). "Improving Students' Writing Skill at the Second Grade of SMAN 1 Andong Boyolali in 2010-2011 Academiuc Year." Unpublished Thesis. UNS

Attamin, Z. (2007). "Improving Students Wqriting Profeciency at Ponorogo Muhammadiyah University." Unpublished Thesis. Ponorogo Muhammadiyah University.

Brown, H. D. (1994). Teaching by rinciple: An International Approach Language Pedagogy.New York: $\quad$ Peson Education Company.

Burner, J. (1985). An Historical and Conceptual Perspective, Culture, Communication, and Cognition. London: Cambridge University Press.

Depdiknas. (2005). Materi Pelatihan Integrasi Bahasa Inggris. Jakarta: Depdiknas.

Effendi, M. (2008). “Improving Students' Writing Descriptive Text at Grade VIII C of MTs N Pulosari Tulungagung through Collaborative Learning." Unpublished Thesis. Malang State University.

Johnson, D. And Johnson, R. (1975). Learning together and Alone, Cooperation, Competition, and Individualization. Engglewood Cliffs, NJ: Prentice- Hall.

Johnson, D. W and Smith, K. A. (1991). Cooperative Learning. Washington DC: George Washington University Press.

Nunan, D. (1999). The Learner-Centred Curriculum. Cambridge: Cambridge University Press. 
Nurjannah, N. (2007). “Improving Students' Language Skill in Writing of SMP Negeri 4 Tasikmalaya." Unpublished Thesis. UPI.

O’malley. (1996). Authentic Assessment for English Language Learners. New York: Addison-Wesley Publishing Company.

Vygotsky, L. S. (1978). Mind and Society: The Development of Higher Mental Processes. Cambridge, MA: Harvard University Press.

Zuhri, S. (2009). "Improving Students 'Ability in Writing Recount Text of the First Year Students of MAN Wilingi Blitar". Unpublished Thesis. Malang State University. 